\title{
Poor grain growth in rice under high temperatures affected by water temperature during vegetative stage
}

\author{
Hiroyuki SHIMONO ${ }^{\dagger}$, and Ayako IsHII \\ (Crop Science Laboratory, Faculty of Agriculture, Iwate University, 3-18-8 Ueda, Iwate, 020-8550, Japan)
}

\begin{abstract}
Poor grain growth caused by high temperatures during the ripening stage is a critical problem for rice production. However, the magnitude of the reduction in grain growth also depends on the temperatures before the ripening stage. We hypothesized that the water temperature $\left(T_{\mathrm{w}}\right)$ during vegetative growth can affect grain growth under high temperatures during the ripening stage. We exposed the japonica cultivar 'Hitomebore' to four levels of $T_{\mathrm{w}}$ during vegetative growth, ranging from 20 to $30^{\circ} \mathrm{C}$, and examined grain growth under subsequent high temperatures during the ripening stage in a 3-year experiment using plants having only main stems produced by removing all tillers. We measured green leaf area, chlorophyll content, spikelet number per panicle, hull length, and grain size. To investigate the contribution of the sink-source balance to grain growth, we examined the effect of the interaction between $T_{\mathrm{w}}$ during vegetative growth and a partial sink-removal treatment on grain weight. High air temperature during the ripening stage decreased grain weight, and low $T_{\mathrm{w}}$ during vegetative growth significantly decreased grain weight under both normal and high air temperatures during the ripening stage, without a significant interaction. The responses of grain weight to $T_{\mathrm{w}}$ during vegetative growth were observed even in plants with partial sink removal. The reduced grain growth under lower $T_{\mathrm{w}}$ during vegetative growth resulted from decreased hull length of the grains. Our results support the hypothesis that low $T_{\mathrm{w}}$ during vegetative growth can decrease grain growth in rice at high air temperatures during the ripening stage. It affects the hull size rather than the sink-source balance.
\end{abstract}

Key words: Chalky grains, Photosynthesis, Rice, Sink-source balance, Water temperature.

\section{Introduction}

Rice (Oryza sativa L.) is a major staple food around the world. Rice production has been increasing to keep up with population growth, but the increased production is largely attributable to the productivity per unit land area rather than to an increasing area of cultivation. However, the increase in rice productivity recently began to slow down (Horie et al., 2005; Long and Ort, 2010). Since the Industrial Revolution, global atmospheric temperatures have been rising steadily owing to increasing production of greenhouse-effect gases, and the rate of temperature increase has been accelerating (IPCC, 2007). The resulting temperature increases are expected to decrease rice productivity,

Received; May 21, 2012.

Accepted; September 7, 2012.

†Corresponding Author: shimn@iwate-u.ac.jp especially in areas that already have a warm climate (Peng et al., 2004; Easterling et al., 2007).

High temperatures during the ripening stage strongly decrease rice productivity by inhibiting the development of sound grains. The optimal daily mean temperature for grain growth is around $22^{\circ} \mathrm{C}$ for temperate japonica rice, and increases above this temperature, especially at night, can decrease grain growth (Matsushima and Wada, 1959; Murata, 1964; Nagato and Ebata, 1965; Wakamatsu et al., 2007). A reduction in grain weight ranging from $10 \%$ to $30 \%$ as a result of high temperatures has been reported (Nagato and Ebata, 1965; Morita et al., 2002, 2004, 2005; Wakamatsu et al., 2007). The reduction typically resulted from decreased grain width and grain thickness rather than decreased grain length (Morita et al., 2002, 2004, 2005; Wakamatsu et al., 2007). Grain appearance also deteriorates as temperatures during the ripening stage rise above $26^{\circ} \mathrm{C}$ as a result of incomplete grain filling, 
resulting in chalky grains with a decreased market value (Wakamatsu et al., 2007). To adapt rice production to the current global warming, it will be necessary to understand the underlying physiological mechanisms that affect rice's tolerance of high temperatures during the ripening stage.

High temperatures during the ripening stage can decrease the carbohydrate supply from vegetative organs to the developing grains (Ishii et al., 1977), resulting in poor grain filling (Matsushima and Wada, 1959; Sato and Inaba, 1976; Kobata and Uemuki, 2004; Tsukaguchi and Iida, 2008). Even when source activity is sufficient, grain growth can decrease at high temperatures because sink activity can be decreased by these high temperatures. Morita et al. (2004) showed that grain growth can decrease when the panicles are exposed to high temperature. Several enzymes responsible for starch synthesis in the developing grains are down-regulated under high temperatures, and enzymes responsible for starch degradation are up-regulated by high temperatures (Lin et al., 2005; Yamakawa et al., 2007). In terms of carbohydrate supply, solar radiation during ripening also affects grain growth under high air temperatures (Matsushima and Manaka, 1957; Tsukaguchi and Iida, 2008).

However, the variations in grain growth cannot be fully explained by temperatures and solar radiation during the ripening stage. Ishizaki (2006) compared the screening methods used to identify cultivars capable of tolerating high temperatures using four independent methods in a 3-year study of 26 cultivars, and showed that the magnitude of the growth reduction differed significantly among methods, cultivars, and years. It is particularly important that there was a significant method $\times$ year interaction in spite of identical conditions during the ripening stage, since this means that the magnitude of the growth reduction is affected by the environment before the ripening stage. Similarly, Omoteno et al. (2003) examined heat tolerance under a fully controlled high-temperature environment when the plants were raised in the field before the ripening stage. They also showed that the magnitude of the reduction in grain growth differed significantly among years. The environmental conditions before the ripening stage therefore appear to be a key factor in determining the quality of grain filling under high temperatures during the ripening stage. However, no studies have tested this hypothesis.
Rice growth is sensitive to temperature during vegetative growth, when the plants actively produce tillers and leaves (Matsushima et al., 1964; Yoshida, 1981; Shimono et al., 2002; Ishii et al., 2011) . For rice plants grown under flooded conditions, water temperature $\left(T_{\mathrm{w}}\right)$ has more important effects on growth than air temperature (Matsushima et al., 1964; Shimono et al., 2002; Ishii et al., 2011), because the shoot meristem is located at the base of the shoot (Yoshida, 1981). Recently, we found that the effects of $T_{\mathrm{w}}$ during vegetative growth can persist after reproductive growth begins. That is, a high $T_{\mathrm{w}}$ during vegetative growth can increase the cold tolerance of rice during reproductive growth and thereby reduce spikelet sterility (Shimono et al., 2007b, 2011, 2012, Shimono and Kanda, 2008). Therefore, we hypothesized that $T_{\mathrm{w}}$ during vegetative growth can affect grain growth under high temperatures during the ripening stage.

\section{Materials and Methods}

\subsection{Plant cultivation}

We transplanted seedlings of the japonica rice cultivar 'Hitomebore', which is a major cultivar in northern parts of Japan, into 4-L pots $(16 \mathrm{~cm}$ in diameter, $20 \mathrm{~cm}$ in height, 1/5000-a Wagner pots; Fujiwara Scientific Company Co., Tokyo, Japan) filled with commercial potting soil (Hokuhoku-baido, Kanuma-Sangyo Co., Kanuma, Japan) that contained $1.4 \mathrm{~g} \mathrm{~N}, 3.6 \mathrm{~g} \mathrm{P}_{2} \mathrm{O}_{5}$, and $1.5 \mathrm{~g} \mathrm{~K}$ per pot. The plants had an average of 4.1 leaves on the main stem in 2008, 5.0 leaves in 2009, and 4.3 leaves in 2010. Plants were grown at Iwate University, Morioka, Japan $\left(39^{\circ} 42^{\prime} \mathrm{N}, 141^{\circ} 8^{\prime} \mathrm{E}\right)$, and transplanted in mid-May (19 May 2008, 14 May 2009, and 20 May 2010). There were 9 seedlings per pot (1 seedling per spot), and we used yearly totals of 23 pots (2008), 12 pots (2009), and 12 pots (2010). To minimize the indirect effects of the sink-source balance caused by differences in the number of tillers, we removed all tillers as they appeared and retained only the main stem (Satake and Koike, 1983).

\subsection{Treatments}

\subsubsection{Water temperatures before heading stage}

The plants were grown under open-air conditions in one tub (1.06 $\mathrm{m} \times 0.73 \mathrm{~m} \times 0.33 \mathrm{~m}$ in depth) for each of the four target levels of $T_{\mathrm{w}}\left(20,23,27\right.$, and $30^{\circ} \mathrm{C}$ ) using the method described in our previous study (Shimono et al., 2011). Stated briefly, a thermostat paired with heating equipment of two 200-W heaters 
(Power-safe-heater with a 200-W limit; Nisso, Saitama, Japan) and cooling equipment of a closed-system bath circulator that supplied cool water $\left(12^{\circ} \mathrm{C}\right)(\mathrm{CA}-1112$; EYELA., Tokyo, Japan) through coils was used to control $T_{\mathrm{w}}$ in the tub (one or two tubs for each $T_{\mathrm{w}}$, and 27 to 54 plants for each $T_{\mathrm{w}}$ ). The treatments were continued from transplanting to panicle initiation (defined as the day when panicle length reached $1.0 \mathrm{~mm}$ based on destructive sampling of one or two plants per $T_{\mathrm{w}}$ treatment) in 2008, 2009, and 2010. $T_{\mathrm{w}}$ was maintained within $\pm 0.8^{\circ} \mathrm{C}$ (standard deviation) of the target temperature during most of the 3 years, except for a $1.5^{\circ} \mathrm{C}$ higher temperature in the $23^{\circ} \mathrm{C}$ treatment in 2008 (Table 1). The depth of water was about $5 \mathrm{~cm}$ from the soil surface. From panicle initiation to the heading stage (defined as the day when the panicle tips emerged from the leaf sheaths), plants were grown at a single $T_{\mathrm{w}}$ (an average of $25.4^{\circ} \mathrm{C}$ ) in 2008 and four levels of $T_{\mathrm{w}}$ in 2009 under open-air conditions.

During vegetative and reproductive growth, air temperatures tended to be lower (by up to $1^{\circ} \mathrm{C}$ ) in the plots with higher $T_{\mathrm{w}}$ because warmer temperatures accelerated vegetative growth, although the magnitude was smaller than the difference in $T_{\mathrm{w}}$. The temperatures were measured by a TR-52 sensor ( $T \& D$ corporation, Nagano, Japan) that had been carefully calibrated using a standard temperature sensor with an accuracy of $\pm 0.01^{\circ} \mathrm{C}$. The air temperature, both aspirat- ed and shaded, was measured at $1.5 \mathrm{~m}$ height in the field at ca. $200 \mathrm{~m}$ apart from the pots. We obtained solar radiation data from Japan Meteorological Agency in Morioka, and have presented the mean values during each stage of development in Table 1. Solar radiation during these growth stages did not show any trends as a result of differences in growth stages at a difference in $T_{\mathrm{w}}$. The pots were randomly positioned within each tub, and were rotated once a week.

\subsubsection{Air temperatures during the ripening stage}

After the full heading stage in 2008 and 2009 and after the panicle initiation stage in 2010, the rice plants were transferred into growth chambers, and were exposed to two air temperature conditions (normal and high) during the ripening stage in 2008, and one hightemperature condition in 2009 and 2010. The difference in the timing of the start of this treatment in 2010 was intended to exclude the possible effects of environmental noise from panicle initiation to heading, when all environmental factors other than $T_{\mathrm{w}}$ were not controlled. The normal air temperature was set at $25 / 20^{\circ} \mathrm{C}$ (day/night, $12 \mathrm{~h}$ ) in a PGW36 growth chamber (Conviron Co., Winnipeg, MB, Canada) in 2008. The high air temperature chamber (Akitsu-Keisoku Co., Tokyo, Japan) was set at $30 / 25^{\circ} \mathrm{C}$ (2008 and 2009) or $27 / 22^{\circ} \mathrm{C}$ (2010). In all cases, light intensity was $170 \mu \mathrm{mol} \mathrm{m} \mathrm{m}^{-2} \mathrm{~s}^{-1}$ photosynthetic active radiation, PAR (measured at the top of the plant).

Table 1. Water temperature $\left(T_{\mathrm{w}}\right)$, air temperature $\left(T_{\mathrm{a}}\right)$, and solar radiation $\left(R_{\mathrm{d}}\right)$ during two growth stages from 2008 to 2010. Except when noted otherwise, plants were grown under open-air conditions.

\begin{tabular}{|c|c|c|c|c|c|c|c|c|}
\hline \multirow[t]{2}{*}{ Year } & \multicolumn{4}{|c|}{ Vegetative growth } & \multicolumn{3}{|c|}{ Reproductive growth } & \multirow[t]{2}{*}{ Grain-filling period } \\
\hline & $\begin{array}{c}\text { Set } \\
T_{\mathrm{w}}\left({ }^{\circ} \mathrm{C}\right) \\
\end{array}$ & $T_{\mathrm{w}}\left({ }^{\circ} \mathrm{C}\right)$ & $T_{\mathrm{a}}\left({ }^{\circ} \mathrm{C}\right)$ & $\begin{array}{c}R_{\mathrm{d}} \\
\left(\mathrm{MJ} \mathrm{m}^{-2} \mathrm{~d}^{-1}\right)\end{array}$ & $T_{\mathrm{w}}\left({ }^{\circ} \mathrm{C}\right)$ & $T_{\mathrm{a}}\left({ }^{\circ} \mathrm{C}\right)$ & $\begin{array}{c}R_{\mathrm{d}} \\
\left(\mathrm{MJ} \mathrm{m}^{-2} \mathrm{~d}^{-1}\right) \\
\end{array}$ & \\
\hline \multirow[t]{4}{*}{2008} & 20 & $19.5 \pm 1.0$ & $19.2 \pm 3.6$ & $18.2 \pm 7.2$ & $25.7 \pm 1.4$ & $23.8 \pm 1.5$ & $16.3 \pm 7.2$ & \multirow{4}{*}{ Growth chambers } \\
\hline & 23 & $24.5 \pm 1.2$ & $18.0 \pm 3.2$ & $18.8 \pm 7.3$ & $25.6 \pm 0.4$ & $23.2 \pm 1.2$ & $15.4 \pm 7.1$ & \\
\hline & 27 & $27.2 \pm 1.6$ & $17.5 \pm 2.8$ & $19.0 \pm 7.3$ & $25.1 \pm 0.3$ & $23.5 \pm 1.3$ & $15.4 \pm 7.2$ & \\
\hline & 30 & $30.4 \pm 1.6$ & $17.5 \pm 2.8$ & $19.0 \pm 7.3$ & $25.3 \pm 0.3$ & $23.5 \pm 1.3$ & $15.4 \pm 7.2$ & \\
\hline \multirow[t]{4}{*}{2009} & 20 & $19.2 \pm 0.7$ & $18.8 \pm 3.4$ & $16.8 \pm 7.9$ & $19.8 \pm 0.3$ & $23.7 \pm 1.4$ & $14.9 \pm 6.9$ & \multirow{4}{*}{ Growth chamber } \\
\hline & 23 & $22.4 \pm 0.6$ & $17.6 \pm 3.2$ & $17.7 \pm 7.6$ & $23.5 \pm 0.3$ & $22.4 \pm 1.6$ & $14.8 \pm 7.6$ & \\
\hline & 27 & $27.0 \pm 1.1$ & $17.4 \pm 3.2$ & $18.3 \pm 7.5$ & $26.6 \pm 0.6$ & $22.1 \pm 1.7$ & $13.7 \pm 7.5$ & \\
\hline & 30 & $29.9 \pm 1.1$ & $17.4 \pm 3.2$ & $18.3 \pm 7.5$ & $30.0 \pm 1.5$ & $22.1 \pm 1.7$ & $13.7 \pm 7.7$ & \\
\hline \multirow[t]{4}{*}{2010} & 20 & $19.9 \pm 0.4$ & $21.1 \pm 4.3$ & $17.5 \pm 7.6$ & & & \multirow{4}{*}{ Growth chambe } & \\
\hline & 23 & $22.8 \pm 0.7$ & $20.2 \pm 4.3$ & $17.8 \pm 7.9$ & & & & \\
\hline & 27 & $26.7 \pm 0.3$ & $19.5 \pm 4.2$ & $17.7 \pm 8.3$ & & & & \\
\hline & 30 & $29.6 \pm 0.3$ & $19.2 \pm 4.1$ & $17.4 \pm 8.5$ & & & & \\
\hline
\end{tabular}

Values are means \pm standard deviations. Vegetative growth $=$ from transplanting to panicle initiation; reproductive growth $=$ from panicle initiation to heading; grain-filling period $=$ from heading to maturity. 
Also, $T_{\mathrm{w}}$ during vegetative growth can affect sinksource balance through affecting spikelet number per panicle even for plants without tillers. To distinguish the direct effect of $T_{\mathrm{w}}$ during vegetative growth on grain growth under high temperatures during the ripening stage from the indirect effect via sink-source balance, we conducted a partial panicle-removal treatment in 2010. All but three rachis branches per panicle (the 4th, 5th, and 6th rachis branches) were excised at the heading stage from plants in all vegetative growth $T_{\mathrm{w}}$ treatments (all plants of two pots per $T_{\mathrm{w}}$ ). This was not performed in the $20^{\circ} \mathrm{C}$ treatment, because there were insufficient plants. The number of grains remaining on these three branches averaged $33 \pm 5$ (standard deviation) per panicle.

\subsection{Measurements}

Dates of panicle initiation and heading (as defined above) were determined. We measured the leaf chlorophyll content in the uppermost leaves using a SPAD502 meter (Konica-Minolta Co., Tokyo, Japan) at the panicle initiation stage. Green leaf area was estimated from leaf length and leaf width in 2010 at the heading stage. At harvest, we counted the total numbers of leaves and spikelets per panicle in all 3 years. After manually threshing the spikelets from the paniclerachis, we hulled them using a Komet III rice huller (Fujiwara Scientific Company Co., Tokyo, Japan). The filled hulled grains were defined as those that did not pass through a $1.7-\mathrm{mm}$ sieve. We measured the length and width of the grains using an RN-300 grain inspector (Kett Co., Tokyo, Japan) and then dried the grains for 1 week at $105^{\circ} \mathrm{C}$ so we could determine their dry weight. The percentage of grains with over 1.7-mm thickness per fertiled grain was calculated. Grain weight was then expressed as the weight based on a $14 \%$ water content. The grain weight, length, and width were calculated using 9 panicles in 2008, 9 to 17 in 2009, and 5 to 15 in 2010. In 2010, we measured the hull length of the grains on the three spikelets in the panicle-removal treatment from five panicles per $T_{\mathrm{w}}$ treatment using a digital vernier micrometer (AD5764-100, A\&D Company, Tokyo, Japan) for a total of 45 spikelets per $T_{\mathrm{w}}$ treatment ( 3 spikelets $\times 3$ rachisbranches $\times 5$ panicles). In the panicle-removal experiment, we also measured the hulled grain weight per panicle, and compared this with the weight detached at the identical position of rachis-branches.

\subsection{Statistical analysis}

We tested for significant differences in grain weight, width, and length in 2008 between $T_{\mathrm{w}}$ treatments during vegetative growth and between air temperatures during the ripening stage, as well as their interaction, using two-way analysis of variance (ANOVA). All analysis was done using Excel 2008 (Microsoft Co., Redmond, WA, USA). We also tested for significant differences in grain weight in 2010 between $T_{\mathrm{w}}$ treatments and between panicle removal treatments, as well as their interaction, using two-way ANOVA. In 2009 and 2010, we used one-way ANOVA to detect significant differences among $T_{\mathrm{w}}$ treatments. We tested the effect of $T_{\mathrm{w}}$ during vegetative growth and phenology on other growth parameters using Pearson's correlation coefficient.

\section{Results}

Panicle initiation dates ranged from 43 to 70 days after transplanting, and heading dates ranged from 64 to 96 days after transplanting (Table 2). The dates were significantly earlier at higher $T_{\mathrm{w}}(r=-0.84$ to $-0.87, P<0.001)$. Total leaf number on the main stem increased significantly with increasing $T_{\mathrm{w}}$ during vegetative growth $(r=0.90, P<0.001)$, associated with a change of panicle initiation $(r=-0.81, P<0.01)$ and heading date $(r=-0.73, P<0.01)$, and the difference between 20 and $30^{\circ} \mathrm{C}$ was up to 2.8 leaves. However, since older leaves senesce and die, the green leaf area at heading was not significantly correlated with increasing $T_{\mathrm{w}}$. The SPAD value of uppermost leaves, which represents the chlorophyll content and photosynthetic capacity, was significantly lower at higher $T_{\mathrm{w}}$ during vegetative growth $(r=-0.72, P<0.01)$. In terms of effects of the sink size, the spikelet number per panicle was not significantly affected by $T_{\mathrm{w}}$ during vegetative growth at either air temperature. Note that since the air temperature treatment started after heading, there was no difference in spikelet number between the normal and high air temperature conditions (measured only in 2008). As an indicator of the sinksource balance, we calculated the ratios of spikelet number per total leaf number, per unit SPAD value, and per unit of green leaf area. None of these ratios was significantly correlated with $T_{\mathrm{w}}$ during vegetative growth. 
Table 2. Effects of water temperature $\left(T_{\mathrm{w}}\right)$ during vegetative growth on developmental stage (panicle initiation date, heading date), total leaf number on the main stem, SPAD reading, green leaf area on the main stem at heading stage, spikelet number per panicle of rice in 2008-2010.

\begin{tabular}{|c|c|c|c|c|c|c|c|c|c|c|c|}
\hline \multirow[t]{2}{*}{ Year } & \multirow[t]{2}{*}{ Tw } & $\begin{array}{l}\text { Panicle } \\
\text { initiation } \\
\text { (PI) }\end{array}$ & $\begin{array}{l}\text { Heading } \\
\text { (HD) }\end{array}$ & \multirow{2}{*}{$\begin{array}{l}\text { Total leaf } \\
\text { number on } \\
\text { the main } \\
\text { stem } \\
\text { (A) }\end{array}$} & \multirow{2}{*}{$\begin{array}{c}\text { SPAD } \\
\text { readings } \\
\text { at uppermost } \\
\text { leaves } \\
(\mathrm{B})\end{array}$} & \multirow{2}{*}{$\begin{array}{c}\text { Green leaf } \\
\text { area at } \\
\text { heading } \\
\text { stage }\left(\mathrm{cm}^{2}\right) \\
\text { (C) }\end{array}$} & \multicolumn{2}{|c|}{$\begin{array}{c}\text { Spikelet } \\
\text { number } \\
\text { per panicle }\end{array}$} & \multirow[t]{2}{*}{$\mathrm{D} / \mathrm{A}$} & \multirow[t]{2}{*}{$\mathrm{D} / \mathrm{B}$} & \multirow[t]{2}{*}{$\mathrm{D} / \mathrm{C}$} \\
\hline & & \multicolumn{2}{|c|}{$\begin{array}{c}\text { Days after } \\
\text { transplanting }\end{array}$} & & & & $\mathrm{CT}$ & $\begin{array}{l}\text { HT } \\
\text { (D) }\end{array}$ & & & \\
\hline \multirow[t]{4}{*}{2008} & 20 & 63 & $90 \pm 0.3$ & $14.4 \pm 0.2$ & $49.0 \pm 0.3$ & - & $135 \pm 4$ & $141_{ \pm 4}$ & 9.80 & 2.88 & - \\
\hline & 23 & 49 & $71 \pm 0.1$ & $15.3 \pm 0.2$ & $46.9 \pm 0.4$ & - & $131 \pm 4$ & $134 \pm 3$ & 8.72 & 2.85 & - \\
\hline & 27 & 44 & $68 \pm 0.3$ & $15.7 \pm 0.2$ & $43.5 \pm 0.4$ & - & $133 \pm 3$ & $137 \pm 5$ & 8.73 & 3.14 & - \\
\hline & 30 & 44 & $69 \pm 0.3$ & $17.0 \pm 0.0$ & $41.4 \pm 1.1$ & - & $135 \pm 4$ & $132 \pm 3$ & 7.76 & 3.18 & - \\
\hline \multirow[t]{4}{*}{2009} & 20 & 70 & $85 \pm 0.4$ & $13.6 \pm 0.1$ & $43.7 \pm 0.8$ & - & - & $88 \pm 4$ & 6.48 & 2.02 & - \\
\hline & 23 & 50 & $73 \pm 0.3$ & $14.9 \pm 0.1$ & $45.1 \pm 1.2$ & - & - & $130 \pm 2$ & 8.71 & 2.88 & - \\
\hline & 27 & 47 & $65 \pm 0.3$ & $16.2 \pm 0.1$ & $39.4 \pm 1.2$ & - & - & $111 \pm 3$ & 6.87 & 2.82 & - \\
\hline & 30 & 47 & $64 \pm 0.5$ & $16.4 \pm 0.1$ & $42.1 \pm 0.6$ & - & - & $101 \pm 2$ & 6.17 & 2.40 & - \\
\hline \multirow[t]{4}{*}{2010} & 20 & 67 & $96 \pm 0.4$ & $15.0 \pm 0.1$ & $46.8 \pm 0.9$ & $235 \pm 9$ & - & $84 \pm 3$ & 5.63 & 1.80 & 0.36 \\
\hline & 23 & 53 & $84 \pm 0.5$ & $14.9 \pm 0.1$ & $44.1 \pm 0.7$ & $294 \pm 16$ & - & $90 \pm 9$ & 6.02 & 2.04 & 0.31 \\
\hline & 27 & 46 & $75 \pm 1.2$ & $15.2 \pm 0.1$ & $45.3 \pm 0.8$ & $238 \pm 17$ & - & $95 \pm 12$ & 6.25 & 2.10 & 0.40 \\
\hline & 30 & 43 & $70 \pm 0.3$ & $16.4 \pm 0.1$ & $42.5 \pm 0.5$ & $298 \pm 7$ & - & $118 \pm 5$ & 7.20 & 2.77 & 0.40 \\
\hline \multirow[t]{3}{*}{$r$} & $T w$ & $-0.87 * * *$ & $-0.84 * * *$ & $0.90 * * *$ & $-0.72 * *$ & $0.45^{\mathrm{ns}}$ & $0.05^{\mathrm{ns}}$ & $0.18^{\mathrm{ns}}$ & $-0.12^{\mathrm{ns}}$ & $0.43^{\mathrm{ns}}$ & $0.64 *$ \\
\hline & PI & - & $0.87 * * *$ & $-0.81 * *$ & $0.52^{\mathrm{ns}}$ & $-0.51^{\mathrm{ns}}$ & $0.41^{\mathrm{ns}}$ & $-0.41^{\mathrm{ns}}$ & $-0.15^{\mathrm{ns}}$ & $-0.58^{*}$ & $-0.45^{\mathrm{ns}}$ \\
\hline & HD & $0.87 * * *$ & - & $-0.73 * *$ & $0.69 *$ & $-0.48^{\mathrm{ns}}$ & $0.55^{\mathrm{ns}}$ & $-0.38^{\mathrm{ns}}$ & $-0.14^{\mathrm{ns}}$ & $-0.60^{\mathrm{ns}}$ & $-0.54^{\mathrm{ns}}$ \\
\hline
\end{tabular}

Average \pm standard error. $r$ is correlation coefficient of each parameters with $T_{\mathrm{w}}$ during vegetative growth over years, panicle initiation date (PI) or heading date (HD) ( $n=4$ or 12 ). ***, **, * indicates the $0.1 \%, 1 \%$ and $5 \%$ level significance and ns indicates no significance.

Grain weight decreased significantly at high air temperature during the ripening stage. The decrease was by an average of $11 \%$ (all $T_{\mathrm{w}}$ treatments combined) as a result of the $5^{\circ} \mathrm{C}$ increase in $T_{\mathrm{a}}$ (Fig. 1a). This decrease corresponded to a comparable decrease in grain width (Fig. 1b) and the percentage of grains with over $1.7 \mathrm{~mm}$ of thickness per fertiled grains (Fig. $1 d$ ), but grain length did not differ significantly between the two air temperatures (Fig. 1c). Higher $T_{\mathrm{w}}$ during vegetative growth significantly increased grain weight, by up to $8 \%$ as a result of a $10^{\circ} \mathrm{C}$ increase in 2008, up to $12 \%$ in 2009 , and up to $22 \%$ in 2010 (Fig. 1a). The slope of grain weight in 2009 was steeper than other 2 years at a range of 20 to $27^{\circ} \mathrm{C}$. The increase in grain weight can be attributed to a significant increase in grain width of $3 \%$ to $8 \%$ with increasing $T_{\mathrm{w}}$ (Fig. 1b), and a significant increase in grain length of by up to 5\% (Fig. 1c), and in grain thickness (Fig. 1d). There was no significant interac- tion for grain weight between $T_{\mathrm{w}}$ during vegetative growth and air temperature during the ripening stage (Fig. 1a).

Figure 2 shows the hull length at different rachisbranches on the panicle. The hull size at each branch decreased initially for $T_{\mathrm{w}}$ from 20 to $23^{\circ} \mathrm{C}$ during vegetative growth, and increased with increasing $T_{\mathrm{w}}$ during vegetative growth, mostly corresponding to the observed response of grain weight (Fig. 1a) and grain length (Fig. 1c) for $T_{\mathrm{w}}$ of above $23^{\circ} \mathrm{C}$.

To minimize the effects of differences in the sinksource balance between $T_{\mathrm{w}}$ treatments during vegetative growth, we conducted a partial panicle-removal treatment (Fig. 3). The grain weight was not significantly affected by this treatment, but it increased significantly with increasing $T_{\mathrm{w}}$ during vegetative growth. This means that the effect of $T_{\mathrm{w}}$ was independent of the sink-source balance. 

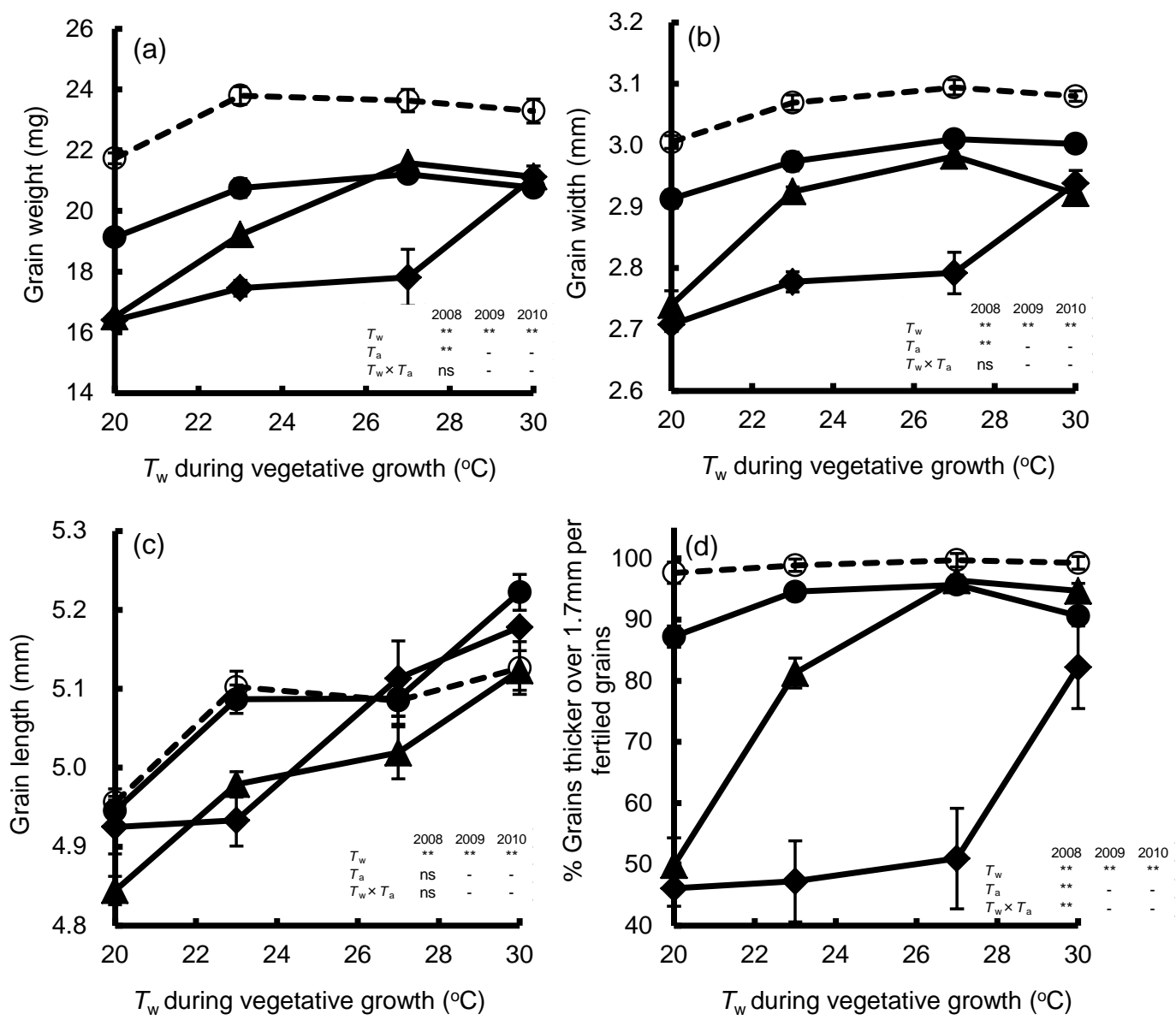

Fig. 1. Effects of water temperature during vegetative growth $\left(T_{w}\right)$ and air temperature during the ripening stage $\left(T_{\mathrm{a}}\right)$ on (a) individual grain weight, (b) grain width, and (c) grain length in rice grown under different air temperatures during the grain-filling stage in 2008, 2009, and 2010. •: High temperature in 2008, $\mathbf{\Lambda}$ : in 2009 and $\diamond$ : in 2010, and $\circ$ : Normal temperature in 2008. Values represent means and standard errors $(n=9$ panicles in 2008, $n=9$ to 17 in 2009, $n=5$ to 15 in 2010). **, $P<0.01$; ns, not significant; -, not tested.

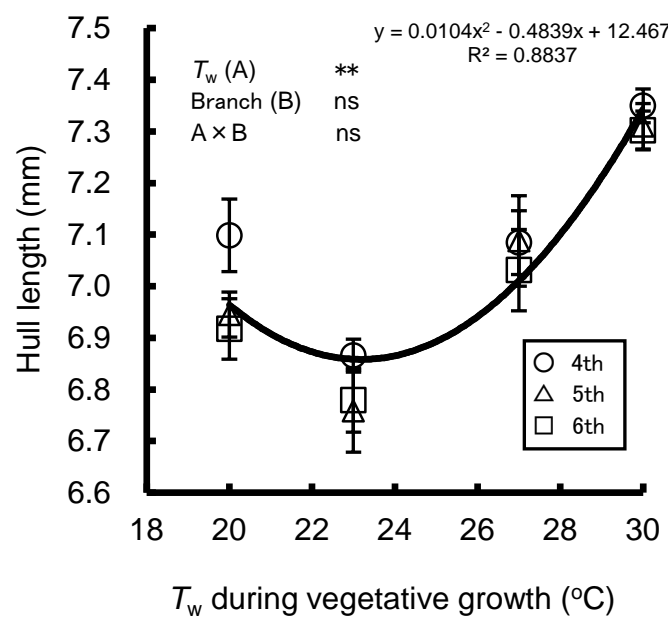

Fig. 2. Effects of water temperature during vegetative growth $\left(T_{\mathrm{w}}\right)$ on the hull length of rice grains on the different rachis-branches (4th, 5th and 6th). Values represent means and standard errors $(n=15$ spikelets per rachis-branch) . ${ }^{* *}, P<0.01$; ns, not significant. 


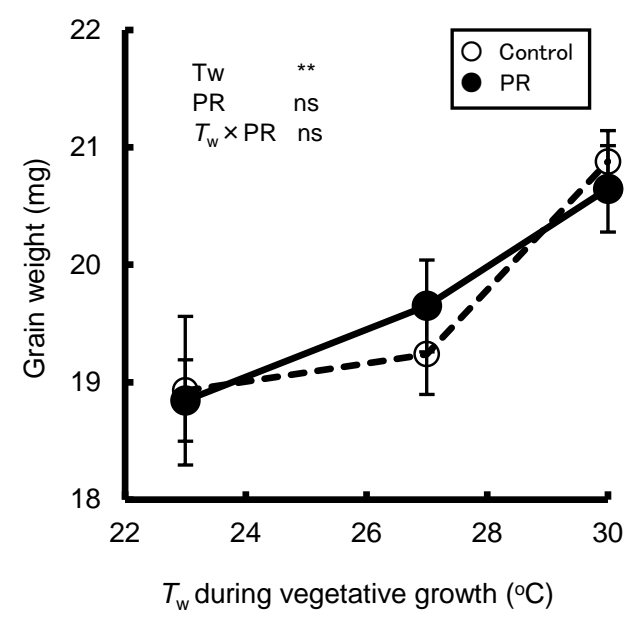

Fig. 3. Effects of water temperature during vegetative growth $\left(T_{\mathrm{w}}\right)$ and panicle removal (PR) on the weight of individual rice grains on the 4th, 5th, and 6th rachis-branches of the panicle. Values represent means and standard errors $(n=6$ to 9 in the PR treatment and $n=2$ to 4 in the control; $n$ represents the number of panicle in which the weight was measured for spikelets pooled for each panicle). **, $P<0.01$; ns, not significant. Values for the $20^{\circ} \mathrm{C}$ treatment are not shown because the treatment of PR could not be conducted.

\section{Discussion}

Our 3-year study showed that higher $T_{\mathrm{w}}$ during vegetative growth, ranging from 20 to $30^{\circ} \mathrm{C}$, significantly increased grain weight under both normal and high air temperatures during ripening, though there was no $T_{\mathrm{w}} \times T_{\mathrm{a}}$ interaction (Fig. 1a). This result partially agrees with Ishii et al. (2011), who examined the effects of high $T_{\mathrm{w}}$ during vegetative growth on grain yield and showed that individual grain weight of field-grown rice was increased by high $T_{\mathrm{w}}$ during vegetative growth in the one year of 2008 out of two years. However, in the other year of 2009 in their study, the opposite result of a decrease of individual grain weight was reported. Their inconsistent result in the field might result from the difference in sink-source balance in 2009, where there was a large stimulation of spikelet number of sink size by high $T_{\mathrm{w}}$ during vegetative growth. Additionally, high $T_{\mathrm{w}}$ advanced the heading date by 4-7 days and this could affect the air temperature during ripening stage. It is difficult to exclude such errors caused by differences in environments and/or plant status in field experiments. The present study is the first study to detect the direct effect of $T_{\mathrm{w}}$ during vegetative growth on grain growth under controlled condition during the ripening stage and also regulating the sink-source balance. The present results support our hypothesis that $T_{\mathrm{w}}$ during vegetative growth would affect grain growth during the ripening stage.

We calculated that the contribution of $T_{\mathrm{a}}$ to grain weight was $11 \%$ per $5^{\circ} \mathrm{C}\left(22 \%\right.$ per $\left.10^{\circ} \mathrm{C}\right)$ during the ripening period, whereas that of $T_{\mathrm{w}}$ ranged from $8 \%$ to $22 \%$ per $10^{\circ} \mathrm{C}$ (Fig. 1a). The magnitude of these two responses to temperature changes was therefore comparable. $T_{\mathrm{w}}$ changes more slowly than $T_{\mathrm{a}}$; for example, Shimono et al. (2007a) reported a $1^{\circ} \mathrm{C}$ increase in $T_{\mathrm{w}}$ per $3^{\circ} \mathrm{C}$ increase in $T_{\mathrm{a}}$. However, the opposite responses to $T_{\mathrm{w}}$ during vegetative growth and to air temperature during ripening suggested that the predicted negative impact of global warming on grain development during the ripening stage (e.g., Easterling et al., 2007) might be alleviated by the effects of high $T_{\mathrm{w}}$ during vegetative growth. This finding is valuable because it will help researchers to analyze the variations in grain growth that will occur and to manage rice plants for tolerance to high temperatures.

Grain growth during the ripening stage is determined by the size of the rigid hull and by the carbohydrate supply to grains, as well as by their use of these carbohydrates. The effects of high $T_{\mathrm{a}}$ during the ripening stage are determined only by the latter factor, since hull size is determined by environmental conditions before the heading stage (Yoshida, 1981). In the present study, the decrease in grain weight caused by high $T_{\mathrm{a}}$ during the ripening stage resulted from decreased grain width (Fig. 1b) and decreased grain thickness (Fig. 1d), not decreased grain length (Fig. 1c). This response agrees with previous results (Morita et al., 2002, 2004, 2005; Wakamatsu et al., 2007). Limitations on the carbohydrate supply or a reduction in sink capacity caused by high temperatures during the grainfilling stage inhibit the development of sound grains (Matsushima and Wada, 1959; Sato and Inaba, 1976; Kobata and Uemuki, 2004; Tsukaguchi and Iida, 2008).

On the other hand, our results showed that $T_{\mathrm{w}}$ during vegetative growth would have a relatively small effect on this latter factor. First, the green leaf area did not 
respond consistently to $T_{\mathrm{w}}$ during vegetative growth, although the total leaf number was higher at higher $T_{\mathrm{w}}$ (Table 2). The chlorophyll content of the uppermost leaves decreased with increasing $T_{\mathrm{w}}$ during vegetative growth. These results suggest that photosynthetic capacity would not increase in plants grown under higher $T_{\mathrm{w}}$ during vegetative growth, although we did not measure the actual rate of photosynthesis to confirm this. Second, the sink size (spikelet number per panicle) did not differ between $T_{\mathrm{w}}$ treatments (Table 2) Because we grew rice with only one panicle per plant, this number represents the total sink size. Third, none of the ratios of sink strength to other parameters significantly correlated with $T_{\mathrm{w}}$ during vegetative growth (Table 2). This means that the effect of the sinksource balance on grain weight would be minor. This was confirmed by our sink limitation treatment, which showed no significant effect on grain weight for the $T_{\mathrm{w}}$ during vegetative growth (Fig. 3 ) .

Thus, hull size appears to have been the key factor responsible for the observed variations in grain weight under different $T_{\mathrm{w}}$ treatments during vegetative growth. The hull size is a genetically determined morphological trait, and represents the potential space in which grains can expand, and therefore constrains the potential sink size (Yoshida, 1981). The hull length decreased significantly under low $T_{\mathrm{w}}$ during vegetative growth although the hull size initially decreased with $T_{\mathrm{w}}$ (Fig. 2). There was a gap of about $30 \%$ between hull length and grain length, but no significant correlation of the gap with $T_{\mathrm{w}}$ (Figs. 1, 2). This suggests that the hull length per se is the one of the key factors that affects grain length. The significant reduction in grain width at low $T_{\mathrm{w}}$ during vegetative growth (Fig. 1b) suggests that hull width also decreased, although we did not measure it.

Few studies have examined the effects of environmental stress on the hull size in rice plants. Environmental stress, especially during the panicle development stage, has been reported to decrease hull size when water deficits occur around the booting stage (Tsuda, 1993) when low $T_{\mathrm{w}}$ occurs after the panicle initiation stage (Tsunoda, 1964) and when salt stress occurs throughout the growing season, including during reproductive growth (Fabre et al., 2005). It should be noted that the present results were caused by $T_{\mathrm{w}}$ differences before the panicle initiation stage, suggesting that hull size can be affected by plant status during vegetative growth.

The yearly difference in the responsiveness to $T_{\mathrm{w}}$ during vegetative growth (Fig. 1abd) might be explained by the treatment period. Plants in 2009 were exposed for longer periods than the other two years of 2008 and 2010, including during reproductive growth in addition to vegetative growth. Since Tsunoda (1964) reported that hull size was significantly reduced by low $T_{\mathrm{w}}$ during reproductive growth per se, the hull size might be more reduced in 2009.

In this study, plant cultivation removing all tillers was adopted. This might have some indirect interference because the $T_{\mathrm{w}}$ during vegetative stage can influence the growth of tiller (Shimono et al., 2002; Ishii et al., 2011), and damage caused by removing the tillers might occur. Further studies will be necessary to determine the physiological mechanisms responsible for the effects of $T_{\mathrm{w}}$ during vegetative growth on hull size using plants without tillers removed.

In conclusion, our results using plants having only the main stem by removing all tillers demonstrate that $T_{\mathrm{w}}$ before the panicle initiation stage can affect the hull size of rice, which in turn determines the potential grain size and grain growth.

\section{References}

Easterling, W. E., Aggarwal, P. K., Batima, P., Brander, K. M., Erda, L., Howden, S. M., Kirilenko, A., Morton, J., Soussana, J. F., Schmidhuber, J., and Tubiello, F. N., 2007: Food, fiber and forest products. In Climate Change 2007: Impacts, adaptation and vulnerability. Contribution of Working Group II to the Fourth Assessment Report of the Intergovernmental Panel on Climate Change (ed. by Parry, M. L., Canziani, O. F., Palutikof, J. P., van der Linden, P. J., and Hanson, C. E.) . Cambridge University Press, Cambridge, UK, pp. 273-313.

Fabre, D., Siband, P., and Dingkuhn, M., 2005: Characterizing stress effects on rice grain development and filling using grain weight and size distribution. Field Crops Res., 92, 11-16.

Horie, T., Shiraiwa, T., Homma, K., Katsura, K., Maeda, S., and Yoshida, H., 2005: Can yields of lowland rice resume the increases that they showed in the 1980s? Plant Prod. Sci., 8, 259-274.

IPCC, 2007: Summary for Policy makers. In Climate Change 2007: The Physical Science Basis. Contribution of Working Group I to the Fourth Assessment 
Report of the Intergovernmental Panel on Climate Change (ed. by Solomon, S., Qin, D., Manning, M., Chen, Z., Marquis, M., Averyt, K. B., Tignor, M., and Miller, H. L.). Cambridge University Press, Cambridge, United Kingdom and New York, NY, USA., pp. 1-18.

Ishii, A., Kuroda, E., and Shimono, H., 2011: Effect of high water temperature during vegetative growth on rice growth and yield under a cool climate. Field Crops Res., 121, 88-95.

Ishii, R., Ohsugi, R., and Murata, Y., 1977: The effect of temperature on the rates of photosynthesis, respiration and the activity of RuDP carboxylase in barley, rice and maize leaves. Jpn. J. Crop Sci., 46, 516-523.

Ishizaki, K., 2006: Evaluation of various screening systems for high grain quality in rice cultivars under high-temperature grain-filling conditions, and the selection of their standard cultivars. Jpn. J. Crop Sci., 75, 502-506 (in Japanese with English abstract).

Kobata, T., and Uemuki, N., 2004: High temperatures during the grain-filling period do not reduce the potential grain dry matter increase of rice. Agron. J., 96, 406-414.

Lin, S. K., Chang, M. C., Tsai, Y. G., and Lur, H. S., 2005: Proteomic analysis of the expression of proteins related to rice quality during caryopsis development and the effect of high temperature on expression. Proteomics, 5, 2140-2156.

Long, S. P., and Ort, D. R., 2010: More than taking the heat: crops and global change. Curr. Opin. Plant Biol., 13, 241-248.

Matsushima, S., and Manaka, T., 1957: Analysis of developmental factors determining yield and yield prediction in lowland rice. XXXIX. On the mechanism of ripening (5). Effects of temperatures and light intensities and their compound conditions in different stages in growth upon the ripening of rice plants. XL. On the mechanism of ripening (6). Effects of the range of daily temperature in different stages in growth upon the ripening of rice plants. Proc. Crop Sci. Jpn., 25, 203-206 (in Japanese with English summary).

Matsushima, S., Tanaka, T., and Hoshino, T., 1964: Analysis of yield-determining process and its application to yield-prediction and culture improvement of lowland rice. LXX. Combined effects of airtemperatures and water-temperatures at different stages of growth on the grain yield and its compo- nents of lowland rice. Proc. Crop Sci. Soc. Jpn., 33, 53-58 (in Japanese with English summary).

Matsushima, S., and Wada, G., 1959: Analysis of developmental factors determining yield and its application to yield prediction and culture improvement of lowland rice. LII. Studies on the mechanism of ripening (10). On the optimum temperature of translocation rate of carbohydrates from leaves and culms to grains and that of ripening as related to the depression of activity of grains in receiving the carbohydrates supplied from leaves and culms. Proc. Crop Sci. Soc. Jpn., 28, 44-45 (in Japanese with English abstract).

Morita, S., Shiratsuchi, H., Takanashi, J., and Fujita, K., 2002: Effect of high temperature on ripening in rice plants - Comparison of the effects of high night temperatures and high day temperatures. Jpn. J. Crop Sci., 71, 102-109 (in Japanese with English abstract).

Morita, S., Shiratsuchi, H., Takahashi, J., and Fujita, K., 2004: Effect of high temperature on grain ripening in rice plants. - Analysis of the effects of high night and high day temperatures applied to the panicle and other parts of the plant. Jpn. J. Crop Sci., 73, 77-83 (in Japanese with English abstract).

Morita, S., Yonemaru, J., and Takanashi, J., 2005: Grain growth and endosperm cell size under high night temperatures in rice (Oryza sativa L.). Ann. Bot., 95, 695-701.

Murata, Y., 1964: On the influence of solar radiation and air temperature upon the local differences in the productivity of paddy rice in Japan. Jpn. J. Crop Sci., 33, 59-63 (in Japanese with English summary).

Nagato, K., and Ebata, M., 1965: Effects of high temperature during ripening period on the development and the quality of rice kernels. Jpn. J. Crop Sci., 34, 59-66 (in Japanese with English summary).

Omoteno, M., Kojima, Y., Ebitani, T., Yamaguchi, T., Mukaino, N., and Yamamoto, Y., 2003: The authorizing method of ripening ability in brown rice quality under artificial high temperature conditions. Hokuriku Crop Sci., 38, 12-14 (in Japanese).

Peng, S., Huang, J., Sheehy, J. E., Laza, R. C., Visperas, R. M., Zhong, X., Centeno, G. S., Khush, G. S., and Cassman, K. G., 2004: Rice yields decline with higher night temperature from global warming. Proc. Natl. Acad. Sci. U.S.A., 101, 9971-9975.

Satake, T., and Koike, S., 1983: Circular dense planting water culture of rice plants, with the purpose of 
obtaining many uniform panicles of main stems from a pot. Jpn. J. Crop Sci., 52, 598-600 (in Japanese).

Sato, K., and Inaba, K., 1976: High temperature injury of ripening in rice plant. V. On the early decline of assimilate storing ability of grains at high temperature. Jpn. J. Crop Sci., 45, 156-161 (in Japanese with English summary).

Shimono, H., and Kanda, E., 2008: Does regional temperature difference before the panicle initiation affect the tolerance for low temperature-induced sterility in rice? Plant Prod. Sci., 11, 430-433.

Shimono, H., Hasegawa, T., and Iwama, K., 2002: Response of growth and grain yield in paddy rice to cool water at different growth stages. Field Crops Res., 73, 67-79.

Shimono, H., Hasegawa, T., Kuwagata, T., and Iwama, K., 2007a: Modeling the effects of water temperature on rice growth and yield under a cool climate: II. Model application. Agron. J., 99, 1338-1344.

Shimono, H., Ishii, A., Kanda, E., Suto, M., and Nagano, K., 2011: Genotypic variation in rice cold tolerance responses during reproductive growth as a function of water temperature during vegetative growth. Crop Sci., 51, 290-297.

Shimono, H., Okada, M., Kanda, E., and Arakawa, I., 2007b: Low temperature-induced sterility in rice: Evidence for the effects of temperature before panicle initiation. Field Crops Res., 101, 221-231.
Shimono, H., Suto, M., and Nagano, K., 2012: Cold tolerance for sterility induced by low temperature at booting stage can be improved by warmer water temperature during vegetative growth. Clim. Bios., 12, 1-5 (in Japanese with English abstract).

Tsuda, M., 1993: Grain filling in rice subjected to drought at three stages. Jpn. J. Crop Sci., 62, 199205 (in Japanese with English abstract).

Tsukaguchi, T., and Iida, Y., 2008: Effects of assimilate supply and high temperature during grain-filling period on the occurrence of various types of chalky kernels in rice plants (Oryza sativa L.). Plant Prod. Sci., 11, 203-210.

Tsunoda, K., 1964: Studies on the effects of watertemperature on the growth and yield in rice plants. Bull. Natl. Inst. Agric. Sci., A11, 75-174 (in Japanese with English abstract).

Wakamatsu, K., Sasaki, O., Uezono, I., and Tanaka, A., 2007: Effects of high air temperature during the ripening period on the grain quality of rice in warm regions of Japan. Jpn. J. Crop Sci., 76, 71-78 (in Japanese with English abstract).

Yamakawa, H., Hirose, T., Kuroda, M., and Yamaguchi, T., 2007: Comprehensive expression profiling of rice grain filling-related genes under high temperature using DNA microarray. Plant Physiol., 144, 258-277.

Yoshida, S., 1981: Fundamentals of rice crop science. IRRI, Los Banos, Philippines, 269 pp. 